\title{
RELIGIUSITAS DENGAN KEPERCAYAAN DIRI PADA PENDERITA SKOLIOSIS DI MASYARAKAT SKOLIOSIS INDONESIA
}

\author{
Isna Asyri Syahrina, Dona Herlinda Efendi, Harry Theozard Fikri \\ Fakultas Psikologi Universitas Putra Indonesia "YPTK" Padang \\ isnaasyrisy@upiyptk.ac.id
}

\begin{abstract}
ABSTRAK: Tujuan penelitian ini adalah untuk mengetahui hubungan antara religiusitas dengan kepercayaan diri pada penderita skoliosis di Masyarakat Skoliosis Indonesia. Variabel independen dalam penelitian ini adalah religiusitas dan variabel dependen adalah kepercayaan diri. Alat ukur yang digunakan dalam penelitian ini adalah skala religiusitas dan skala kepercayaan diri. Teknik pengambilan sampel yang digunakan adalah purposive sampling. Sampel dalam penelitian ini adalah penderita skoliosis anggota group line di Masyarakat Skoliosis Indonesia yang berjumlah 72 orang. Uji validitas dan reliabilitas teknik Alpha Cronbach. Koefisien validitas pada skala religiusitas bergerak dari $r_{i x}=0,311$ sampai $r_{i x}=0,736$, sedangkan koefisien reliabilitas sebesar 0,943. Sementara itu koefisien validitas pada skala kepercayaan diri bergerak dari $r_{i x}=0,310$ sampai dengan $r_{i x}=0,731$, sedangkan koefisien reliabilitas sebesar 0,927. Uji hipotesis menggunakan teknik korelasi Product Moment Pearson. Hasil analisis data menunjukkan koefisien korelasi $r_{x y}=0,681$ dengan taraf signifikan $p=0,000$. Artinya terdapat hubungan yang positif dan signifikan antara religiusitas dengan kepercayaan diri pada penderita skoliosis di Masyarakat Skoliosis Indonesia
\end{abstract}

Kata Kunci : Religiusitas, Kepercayaan diri, Skoliosis.

ABSTRACT: The purpose of this study was to determine the relationship between religiosity and self-confidence in scoliosis patients in the Indonesian Scoliosis Society. The independent variable in this study is religiosity and the dependent variable is self-confidence. The measuring instrument used in this study is the scale of religiosity and the scale of selfconfidence. The sampling technique used was purposive sampling. The sample in this study were scoliosis sufferers who were members of the group line in the Indonesian Scoliosis Society, amounting to 72 people. Test the validity and reliability of the Cronbach Alpha technique. The validity coefficient on the religiosity scale moves from rix $=0.311$ to rix $=$ 0.736, while the reliability coefficient is 0.943. Meanwhile the validity coefficient on the confidence scale moves from rix $=0.310$ to rix $=0.731$, while the reliability coefficient is 0.927. Hypothesis testing uses the Pearson Product Moment correlation technique. The results of data analysis showed the rxy correlation coefficient $=0.681$ with a significant level of $p=0,000$. This means that there is a positive and significant relationship between religiosity and self-confidence in scoliosis sufferers in the Indonesian Scoliosis Society

Keywords: Religiosity, Confidence, Scoliosis.

PENDAHULUAN

Sehat menurut WHO (World yang sempurna baik fisik, mental dan sosial tidak hanya bebas dari penyakit atau kelemahan. Kesehatan menurut undang-
Health Organization) adalah suatu keadaan
P-ISSN: 0853-8050 E-ISSN: 2502-6925 
undang RI no 36 tahun 2009 adalah keadaan sehat baik secara fisik, mental dan spiritual maupun sosial yang memungkinkan setiap orang untuk hidup produktif secara sosial dan ekonomi.

Konsep sehat dan sakit menurut Departemen Kesehatan RI sesungguhnya tidak terlalu mutlak dan universal karena ada faktor -faktor lain di luar kenyataan klinis yang mempengaruhinya terutama faktor sosial budaya. Setiap pengertian saling mempengaruhi dan pengertian yang satu hanya dapat dipahami dalam konteks pengertian yang lain. Banyak ahli filsafat, biologi, antropologi, sosiologi, kedokteran, dan lain-lain bidang ilmu pengetahuan telah mencoba memberikan pengertian tentang konsep sehat dan sakit ditinjau dari masing-masing disiplin ilmu. Masalah sehat dan sakit merupakan proses yang berkaitan dengan kemampuan atau ketidakmampuan manusia beradaptasi dengan lingkungan baik secara biologis, psikologis maupun sosiobudaya.
Adillani (2015) mengatakan sehat berarti seseorang harus diberi kesempatan seluas-luasnya untuk mengembangkan kemampuan yang dibawa sejak lahir (potensial genetik) menjadi realitas fenotipik (phenotypic ralities).

Tingkat perkembangan individu dalam populasi memicu adanya berbagai faktor yang berisiko terhadap kesehatan beserta dampak lanjutannya, sehingga setiap populasi perkembangan dapat dikategorikan sebagai populasi at risk. Salah satu tingkat perkembangan tersebut adalah tahap perkembangan remaja dimana masa remaja merupakan fase tumbuh kembang yang dinamis dalam kehidupan seorang individu dan remaja mengalami periode transisi perkembangan dari masa kanak-kanak ke masa dewasa (dalam Mukaromah, 2011).

Papalia, Olds \& Feldman (2009) mengungkapkan masa remaja merupakan peralihan masa perkembangan antara masa kanak-kanak ke masa dewasa yang 
meliputi perubahan besar pada aspek fisik, kognitif dan psikososial. Masa remaja secara umum dimulai dengan pubertas, yaitu proses yang mengarah kepada kematangan seksual dan kemampuan untuk bereproduksi. Perubahan biologis pubertas yang merupakan tanda akhir masa kanakkanak, berakibat pada peningkatan pertumbuhan berat dan tinggi badan, perubahan dalam proporsi dan bentuk tubuh, serta pencapaian kematangan organ seksual.

\section{Wertheim \& Paxton (dalam} Mukaromah, 2011) mengatakan selama menjalani masa pubertas, remaja rentan dengan berbagai masalah fisik, mulai dari munculnya jerawat, bertambahnya lemak di bagian tubuh tertentu, dan sebagainya. Selain masalah-masalah tersebut, remaja yang sedang mengalami maturasi tulang juga beresiko mengalami kelainan tulang belakang, salah satunya skoliosis.

Menurut Soetjaningsih (dalam deformitas tulang belakang berupa deviasi vertebra ke arah samping atau lateral. Situs RS Bina Sehat (dalam Fera, 2015) menjelaskan bahwa pada masyarakat Indonesia sendiri, skoliosis masih belum begitu dikenal, baik mengenai jenis kelainannya, penyebab, gejala, dan penanganannya. Secara sederhana, Anderson menjelaskan skoliosis sebagai kondisi lekukan tulang belakang yang abnormal. Namun, sebenarnya terjadi perubahan yang cukup signifikan pada tulang belakang akibat perubahan bentuk tulang belakang secara 3 (tiga) dimensi.

Skolioser, istilah yang sering digunakan oleh para penderita skoliosis untuk menyebut diri mereka. Para skolioser diseluruh nusantara berbagi keluhan, ketidaknyamanan mereka dan memberikan motivasi dari pengalaman sendiri yang mereka tuangkan dalam organisasi yang bernama MSI (Masyarakat Skoliosis Indonesia).

Faturrahman, 2013), skoliosis adalah 
Eka Kartika Sanur selaku sekretaris

MSI mengatakan MSI adalah sebuah

organisasi yang berperan sebagai pusat

informasi skoliosis dan sebagai wadah

pemersatu bagi penderita dan pemerhati

skoliosis di Indonesia (dalam Hanum dan

Nilamsari, 2009). MSI didirikan di

Bandung, Jawa Barat dan berpusat di

Jakarta. Adanya keterbatasan waktu dari

semua skolioser diseluruh nusantara,

mereka berkomunikasi melalui sosial

media.

Skoliosis memang tidak

menimbulkan rasa nyeri, namun dapat mengganggu rasa percaya diri anak, yang pasti skoliosis berbahaya bila terjadi pada masa pertumbuhan tulang. Pasalnya, selain akan semakin progresif, juga berpengaruh pada postur tubuh, seperti jalan pincang karena pinggul tinggi sebelah atau bisa juga tubuhnya jadi membungkuk ke depan (dalam Rosadi, 2009).

Soetedjo (dalam Fera, 2015) mengungkapkan bahwa angka kasus skoliosis adalah $2 \%$ dari jumlah populasi.

Skoliosis juga lebih sering terjadi ditemukan pada perempuan daripada lakilaki. Ditambah lagi, skoliosis pada perempuan lebih progresif daripada skoliosis pada laki-laki.

Rothman (dalam Alfiana, Wulan dan Malau, 2016) mengatakan skoliosis ialah istilah perubahan yang merujuk kepada keadaan tidak normal di mana tulang belakang seseorang membengkok ke kanan atau ke kiri. Umumnya Skoliosis ini muncul semenjak usia anak-anak atau remaja dan jarang terjadi pada usia dewasa. Dampak yang ditimbulkan selain rasa sakit juga dampak mental bagi penderita Skoliosis. Dalam pergaulan sehari-harinya, penderita skoliosis sering sekali kehilangan rasa percaya diri karena bentuk tubuh yang tidak normal.

Perry (dalam Rombe, 2014) mengatakan kepercayaan diri merupakan suatu kemampuan untuk memercayai kemampuan sendiri dan merasa positif 
tentang apa yang bisa dilakukan dan tidak mengkhawatirkan apa yang tidak bisa dilakukan. Hakim (dalam Putri, 2015) mengemukakan Kepercayaan diri merupakan keyakinan seseorang terhadap segala kelebihan aspek yang dimilikinya dan keyakinan tersebut membuatnya merasa mampu untuk bisa untuk mencapai berbagai tujuan di dalam hidupnya.

Mc Guire (dalam Khoesdianto, 2009), mengatakan rasa percaya diri sangat dipengaruhi oleh sistem nilai atau norma yang dimiliki individu. Sistem ini berawal dari faktor eksternal seseorang, yaitu melalui proses belajar dan sosialisasi dari lingkungan. Koentjaraningrat (dalam Khoesdianto, 2009) membagi lima macam norma yang ada di lingkungan, yaitu norma agama, norma kesusilaan, norma kesopanan, norma kebiasaan dan norma hukum. Dari kelima norma yang ada, norma yang paling berpengaruh adalah norma agama karena agama dipercaya berasal dari kekuatan gaib, kuasa yang lebih tinggi, kuasa yang mutlak, kuasa yang ilahi, kuasa yang menciptakan alam semesta beserta isinya, kuasa yang menguasai manusia, yang transenden tidak terungkap dalam kata-kata dan bahasa, dan karena itu berpengaruh terhadap aspek kehidupan manusia.

Berdasarkan perangkat norma yang diperoleh seseorang dari hasil belajar dan sosialisasi akhirnya meresap dan menjadi faktor internal (diinternalisasikan) dalam dirinya. Menurut Hendropuspito (dalam Khoesdianto, 2009) hasil internalisasi dari norma agama itu dinamakan religiusitas.

Hawari (dalam Wahaningsih, 2012) menyebutkan bahwa religiusitas merupakan penghayatan keagamaan dan kedalaman kepercayaan yang diekspresikan dengan melakukan ibadah sehari-hari, berdoa, dan membaca kitab suci. Menurut Nashori (dalam Reza, 2013) religiusitas adalah seberapa jauh pengetahuan, seberapa kokoh keyakinan, seberapa pelaksanaan ibadah dan kaidah, 
dan seberapa dalam penghayatan atas agama yang dianut.

$$
\text { Mukti (2013) mengatakan }
$$

keyakinan akan membuahkan kepasrahan dan kepercayaan bahwa segala sesuatunya itu sudah ditentukan oleh yang di atas. Pada keyakinan ini agama memegang peranan penting sebagai pegangan hidup penderita. Agama akan membantu penderita dalam memaknai hidupnya dan akan terealisasikan dalam sistem hidup, sikap dan perilaku serta pikiran yang positif.

Dari hasil Wawancara terhadap wakil ketua Masyarakat Skoliosis Indonesia ditemukan bahwa skolioser (penderita skoliosis) mengeluh mengenai fisik mereka. Skolioser merasa berbeda dan menyalahkan kondisi saat ini baik keluhan dari skala normal sampai berlebihan. Pernyataan ini dikuatkan oleh lima orang skolioser yang peneliti wawancarai. Mereka mengatakan bahwa mereka minder dengan orang normal, menarik diri dari kehidupan sosial, sensitif dan takut membuat kesalahan. Hal lain yang ditemukan, mereka merasa sedih diciptakan berbeda dari lingkungan sekitar, mereka merasa tuhan tidak sayang kepada mereka karena bentuk fisik mereka yang berbeda dan mereka tidak yakin dengan mereka beribadah mereka akan sembuh.

\section{Kepercayaan Diri}

Lauster (dalam Ghufron \& Risnawita, 2010) mengatakan kepercayaan diri diperoleh dari pengalaman hidup. Kepercayaan diri merupakan salah satu aspek kepribadian yang berupa keyakinan akan kemampuan diri seseorang sehingga tidak terpengaruh oleh orang lain dan dapat bertindak sesuai kehendak, gembira, optimis, cukup toleran, dan bertanggung jawab.

Fatimah (2010) berpendapat kepercayaan diri adalah sikap positif seorang individu yang memampukan dirinya untuk mengembangkan penilaian 
positif, baik terhadap dirinya sendiri maupun terhadap lingkungan/situasi yang dihadapinya. Hal ini bukan berarti individu tersebut mampu dan kompeten melakukan segala sesuatu seorang diri, alias "sakit".

Menurut Taylor (dalam Wahyuni, 2014) kepercayaan diri adalah keyakinan seseorang akan kemampuan yang dimiliki untuk menampilkan perilaku tertentu atau untuk mencapai target tertentu. Dengan kata lain, kepercayaan diri adalah bagaimana kita merasakan tentang diri kita sendiri, dan perilaku kita akan merefleksikan tanpa kita sadari. Kepercayaan diri bukan merupakan bakat (bawaan), melainkan kualitas mental, artinya kepercayaan diri merupakan pencapaian yang dihasilkan dari proses pendidikan atau pemberdayaan. Kepercayaan diri dapat dilatih atau dibiasakan.

$$
\text { Kumara (dalam Ghufron \& }
$$

Risnawita, 2010) menyatakan bahwa kepercayaan diri merupakan ciri kepribadian yang mengandung arti keyakinan terhadapa kemampuan sendiri. Hal ini senada dengan pendapat Afiatin dan Handayani (dalam Ghufron \& Risnawita) yang menyatakan bahwa kepercayaan diri merupakan aspek kepribadian yang berisi keyakinan tentang kekuatan, kemampuan, dan keterampilan yang dimilikinya.

Menurut Lauster (dalam Ghufron \& Risnawita, 2010), orang yang memiliki kepercayaan diri yang positif adalah yang disebutkan di bawah ini:

a. Keyakinan kemampuan diri adalah sikap positif seseorang tentang dirinya. Ia mampu secara sungguh-sungguh akan apa yang dilakukannya.

b. Optimis adalah sikap positif yang dimiliki seseorang yang selalu berpandangan baik dalam menghadapi segala hal tentang diri dan kemampuannya.

c. Objektif: Orang yang memandang permasalahan atau sesuatu sesuai 
dengan kebenaran yang semestinya,

bukan menurut kebenaran pribadi atau menurut dirinya sendiri.

d. Bertanggung jawab adalah kesediaan orang untuk menanggung segala sesuatu yang telah menjadi konsekuensinya.

e. Rasional dan realistis adalah analisis terhadap suatu masalah, sesuatu hal, dan suatu kejadian dengan menggunakan pemikiran yang dapat diterima oleh akal dan sesuai dengan kenyataan.

Faktor-faktor yang mempengaruhi kepercayaan diri individu menurut Ghufron \& Risnawita (2010) adalah:

a. Konsep diri yang positif akan membentuk harga diri yang positif pula.

b. Harga diri adalah penilaian yang dilakukan terhadap diri sendiri.

c. Pengalaman dapat menjadi faktor munculnya rasa percaya diri. Sebaliknya, pengalaman juga dapat menjadi faktor menurunnya rasa percaya diri seseorang. d. Tingkat pendidikan seseorang akan berpengaruh terhadap tingkat kepercayaan diri seseorang. Tingkat pendidikan yang rendah akan menjadikan orang tersebut tergantung dan berada di bawah kekuasaan orang lain yang lebih pandai darinya. Sebaliknya, orang yang mempunyai pendidikan tinggi akan memiliki tingkat kepercayaan diri yang lebih dibandingkan yang berpendidikan rendah.

\section{Menurut Hakim (dalam Utami,} 2009) rasa percaya diri tidak muncul begitu saja pada diri seseorang. Terdapat proses tertentu di dalam pribadi seseorang sehingga terjadilah pembentukan rasa percaya diri. Secara garis besar terbentuknya rasa percaya diri yang kuat terjadi melalui proses berikut ini, yaitu:

a. Terbentuknya kepribadian yang baik sesuai dengan proses perkembangan yang melahirkan kelebihan-kelebihan tertentu 
b. Pemahaman seseorang terhadap kelebihan-kelebihan yang dimilikinya dan melahirkan keyakinan kuat untuk bisa berbuat segala sesuatu dengan memanfaatkan kelebihan-kelebihannya

c. Pemahaman dan reaksi positif seseorang terhadap kelemahan-kelemahan yang dimilikinya agar tidak menimbulkan rasa rendah diri atau rasa sulit menyesuaikan diri

d. Pengalaman didalam menjalani berbagai aspek kehidupan dengan menggunakan segala kelebihan yang ada pada dirinya.

\section{Religiusitas}

Religiusitas menurut Glock dan Stark (dalam Astuti, 2008) adalah seberapa jauh pengetahuan, seberapa kokoh keyakinan, seberapa tekun pelaksanaan ibadah dan seberapa dalam penghayatan agama yang dianut seseorang. Shadily (dalam Astuti, 2008) mengatakan religiusitas (keberagamaan) diwujudkan dalam berbagai sisi kehidupan manusia.
Hal ini perlu dibedakan dari agama, karena konotasi agama biasanya mengacu pada kelembagaan yang bergerak dalam aspekaspek yuridis, aturan dan hukuman sedangkan religiusitas lebih pada aspek "lubuk hati" dan personalisasi dari kelembagaan tersebut.

Ancok dan Suroso (dalam Wahaningsih, 2012) mendefinisikan religiusitas sebagai keberagamaan yang berarti meliputi berbagai macam sisi atau dimensi yang bukan hanya terjadi ketika seseorang melakukan perilaku ritual (beribadah), tapi juga ketika melakukan aktivitas lain yang didorong oleh kekuatan supranatural. Sumber jiwa keagamaan itu adalah rasa ketergantungan yang mutlak (sense of depend). Adanya ketakutanketakutan akan ancaman dari lingkungan alam sekitar serta keyakinan manusia itu tentang segala keterbatasan dan kelemahannya. Rasa ketergantungan yang mutlak membuat manusia mencari kekuatan sakti dari sekitarnya yang dapat 
dijadikan sebagai kekuatan pelindung dalam kehidupannya dengan suatu kekuasaan yang berada di luar dirinya yaitu Tuhan.

Anshori (dalam Ghufron \& Risnawati, 2010) membedakan antara istilah religi atau agama dengan religiusitas. Jika agama menunjukkan pada aspek-aspek formal yang berkaitan dengan aturan dan kewajiban, maka religiusitas menunjukkan pada aspek religi yang dihayati oleh seseorang dalam hati.

Menurut Hardjana (dalam Pratama, 2015) religiusitas dimaknai sebagai rasa dan kesadaran akan hubungan dalam diri individu dengan Tuhan. Religiusitas secara tidak langsung menjadikan hidup seseorang lebih dekat dengan nilai-nilai yang ada di dalam ajaran agamanya dalam setiap aspek kehidupannya.

Menurut Nashori (dalam Reza, 2013) religiusitas adalah seberapa jauh pengetahuan, seberapa kokoh keyakinan, seberapa pelaksanaan ibadah dan kaidah, dan seberapa dalam penghayatan atas agama yang dianut.

Dimensi religiusitas menurut Glock dan Stark (dalam Ghufron \& Risnawita, 2010) terdiri dari lima dimensi, yaitu:

a. Dimensi keyakinan adalah tingkatan sejauh mana seseorang menerima dan mengakui hal-hal yang dogmatik dalam agamanya. Misalnya keyakinan adanya sifat-sifat Tuhan, adanya malaikat, surga, para Nabi, dan sebagainya.

b. Dimensi peribadatan atau praktik agama adalah tingkatan sejauhmana seseorang menunaikan kewajiban-kewajiban ritual dalam agamanya. Misalnya menunaikan shalat, zakat, puasa, haji, dan sebagainya.

c. Dimensi feeling atau Penghayatan adalah perasaan keagamaan yang pernah dialami dan dirasakan seperti merasa dekat dengan Tuhan, ternteram saat berdo'a, tersentuh mendengar ayat kitab suci, merasa takut berbuat dosa, merasa 
senang do'anya dikabulkan, dan sebagainya.

d. Dimensi pengetahuan agama adalah seberapa jauh seseorang mengetahui dan memahami ajaran-ajaran agamanya terutama yang ada dalam kitab suci, hadis, pengetahuan tentang fikih, dan sebagainya.

e. Dimensi effect atau pengalaman adalah sejauh mana implikasi ajaran agama mempenaruhi perilaku sesorang dalam kehidupan sosial. Misalnya mendermakan harta untuk keagamaan dan sosial, menjenguk orang sakit, mempererat silaturrahmi, dan sebagainya.

Thoules (dalam Wahaningsih, 2012) menyebutkan beberapa faktor yang mempengaruhi religiusitas, yaitu:

a. Pengaruh pendidikan atau pengajaran dan berbagai tekanan sosial (faktor sosial) yang mencakup semua pengaruh sosial dalam perkembangan sikap keagamaan, termasuk pendidikan orang tua, tradisi-tradisi sosial untuk menyesuaikan dengan berbagai pendapatan sikap yang disepakati oleh lingkungan.

b. Berbagai pengalaman yang dialami oleh individu dalam membentuk sikap keagamaan terutama pengalaman mengenai:

1) Keindahan, keselarasan dan kebaikan di dunia lain (faktor alamiah)

2) Adanya konflik moral (faktor moral)

3) Pengalaman emosional keagamaan (faktor afektif)

c. Faktor-faktor yang seluruhnya atau sebagian timbul dari kebutuhankebutuhan yang tidak terpenuhi, terutama kebutuhan terhadap keamanan, cinta kasih, harga diri, dan ancaman kematian.

d. Proses pemikiran verbal atau proses intelektual. 


\section{Skoliosis}

Weiss (2013) menyatakan skoliosis adalah istilah yang digunakan untuk mengacu pada kelengkungan lateral (ke samping) tulang belakang yang tidak bisa diperbaiki sepenuhnya. Kelengkungan lateral (ke samping) seperti ini dibarengi dengan terpelintirnya tulang-tulang tubuh, yang menghasilkan punuk tulang rusuk atau tonjolan pinggang. Menurut Gatam (dalam Hanum, 2009) skoliosis adalah kelengkungan tulang belakang yang abnormal ke arah samping, umumnya seseorang yang menderita skoliosis tingkat ringan seringkali punggungnya terasa nyeri dan turunnya rasa percaya diri akibat perubahan struktur tubuh maupun pembatasan aktifitas harian akibat ketidaknormalan struktur tulang belakang. Sedangkan dalam tingkat berat dapat mengakibatkan kecacatan fisik, gangguan pernafasan dan sebagainya sehingga hal ini sering menjadi beban bagi para penderitanya.
Weiss (2013) mengatakan skoliosis dapat memiliki banyak penyebab yang berbeda. Ada skoliosis karena penyakit saraf dan otot, gangguan metabolik, juga skoliosis bawaan dengan tulang belakang dan pertumbuhan tulang rusuk yang rusak. Skoliosis menurut National Institute of Arthitis and Musculoskeletal and Skin Disease (NIAMS) USA merupakan kelainan muskuloskeletal yang digambarkan dengan bengkoknya tulang belakang ke arah samping. 80-85\% kasus yang dijumpai merupakan tipe idiopatik skoliosis yang ditemukan pada masa pubertas, pada perempuan ditemukan lebih banyak dari pada laki-laki, bisa diakibatkan dari faktor keturunan (dalam Adillani, 2015). Prosedur pengukuran skoliosis diantaranya, radiografi, prosedur pengukuran klinis, topografi permukaan. Pengobatan skoliosis dalam kasus kelengkungan kecil, terutama dimaksudkan untuk mencegah agar tidak bertambah besar. Untuk kelengkungan 
besar, tujuannya adalah untuk mengurangi

akibat dari skoliosis. Beberapa pengobatannya antara lain: pengobatan

fisioterapi, pengobatan menggunakan korset, serta operasi.

\section{METODE}

Populasi adalah wilayah generalisasi yang terdiri atas objek atau subjek yang mempunyai kualitas dan karakteristik tertentu yang ditetapkan oleh peneliti untuk dipelajari dan kemudian ditarik kesimpulannya (Sugiyono, 2013). Populasi dalam penelitian ini adalah seluruh penderita skoliosis dalam grup line anggota Masyarakat Skoliosis Indonesia (MSI) yang berjumlah 102 orang. Adapun teknik pengambilan sampel pada penelitian ini adalah Purposive Sampling, sehingga sampel berjumlah 72 orang.

Alat ukur yang digunakan berupa skala model likert yang mengukur religiusitas dan kepercayaan diri. Skala menurut Azwar (2014) memiliki karakteristik khusus yang membedakannya dari berbagai bentuk instrumen pengumpulan data yang lain seperti angket (questionnaire), daftar isi, dan lain-lainnya. Skala dalam penelitian ini memiliki format respon dengan empat alternatif jawaban, kemudian dianalisis dengan menggunakan teknik korelasi Product Moment Pearson, yang merupakan salah satu teknik untuk mencari derajat keeratan atau keterkaitan pengaruh antara variabel independen dengan variabel dependen (Azwar 2014).

Skala penelitian akan melewati berbagai tahap analisis yaitu uji validitas, sejauh mana instrumen itu mengukur apa yang seharusnya diukur (Azwar, 2014). Sebuah instrumen dikatakan valid, apabila mampu mengukur apa yang diinginkan atau dapat mengungkapkan data dari variabel yang diteliti secara tepat. Uji Reliabilitas adalah derajat ketepatan, ketelitian, atau keakuratan yang ditunjukkan oleh instrumen pengukuran. Sejauh mana suatu alat ukur dapat dipercaya dan diandalkan (Azwar, 2014). 
Apabila suatu alat dapat dipakai dua kali untuk pengukuran yang sama, dan hasil pengukuran itu relatif konsisten, maka alat ukur tersebut dikatakan reliabel. Reliabilitas harus menunjukkan konsistensi atau suatu alat ukur dalam mengukur alat ukur yang sama (Azwar, 2014). Koefisien validitas dilambangkan dengan $r_{i x}$. Reliabilitas dinyatakan oleh koefisien reliabilitas $\left(\mathrm{r}_{\mathrm{xx}}\right)$ yang angkanya berkisar antara 0 sampai dengan 1,00 . Selain itu juga dilakukan uji normalitas yang digunakan untuk mengetahui apakah populasi data terdistribusi normal atau tidak. Uji normalitas menggunakan uji kolmogorov-Smirnov. Uji linearitas bertujuan untuk mengetahui apakah dua variabel mempunyai hubungan yang linear atau tidak. Dua variabel dikatakan mempunyai hubungan yang linier bila signifikansi (linearity) kurang dari 0,05

\section{HASIL DAN PEMBAHASAN}

Hasil

Koefisien validitas skala religiusitas bergerak dari $r_{i x}=0,311$ sampai dengan $r_{i x}=0,736$ dan koefisien reliabilitas sebesar $\alpha=0,943, \quad$ sedangkan untuk skala kepercayaan diri, diperoleh nilai koefisien validitas bergerak dari $r_{i x}=0,310$ sampai dengan $r_{i x}=0,731$ dan koefisien reliabilitas sebesar $\alpha=0,927$. Hasil Uji normalitas dapat dilihat pada tabel 1 berikut ini: :

Tabel 1. Uji Normalitas Skala Religiusitas Dengan Kepercayaan Diri

\begin{tabular}{lcccc}
\hline \multicolumn{1}{c}{ Variabel } & N & KSZ & P & Sebaran \\
\hline Religiusitas & 72 & 0,642 & 0,805 & Normal \\
Kepercayaan Diri & 72 & 0,682 & 0,741 & Normal \\
\hline
\end{tabular}

Berdasarkan tabel 1 di atas, religiusitas sebesar $\mathrm{p}=0,805$ dengan diperoleh nilai signifikansi pada skala $\mathrm{KSZ}=0,642$. Hasil tersebut menunjukkan 
bahwa nilai $\mathrm{p}>0,05$, artinya sebaran

berdistribusi secara normal sedangkan

untuk skala kepercayaan diri sebesar

$\mathrm{p}=0,741$ dengan $\mathrm{KSZ}=0,682$, hasil tersebut menunjukkan bahwa nilai $\mathrm{p}>0,05$, artinya sebaran berdistribusi secara normal. Hasil Uji linieitas, dapat dilihat pada tabel 2 berikut ini:

Tabel 2. Uji Linieritas Skala Religiusitas Dengan Kepercayaan Diri

\begin{tabular}{ccccc}
\hline $\mathbf{N}$ & $\mathbf{d f}$ & $\begin{array}{c}\text { Mean } \\
\text { Square }\end{array}$ & $\mathbf{F}$ & Sig \\
\hline 72 & 1 & 7153,75 & 56,181 & 0 \\
\hline
\end{tabular}

Berdasarkan tabel 2 di atas, diperoleh nilai $\mathrm{F}$ sebesar 56,181 dengan signifikansi sebesar $\mathrm{p}=0,000 \quad(\mathrm{p}<0,05)$ artinya varians pada skala religiusitas dan kepercayaan diri tergolong linier.

Dari hasil pengolahan data penelitian tentang hubungan antara religiusitas dengan kepercayaan diri pada penderita skoliosis di Masyarakat Skoliosis Indonesia dengan sampel penelitian berjumlah 72 maka diperoleh hasil $r_{x y}=0,681$ dengan taraf signifikansi $\mathrm{p}=0,000$, maka dapat disimpulkan terdapat hubungan antara religiusitas dengan kepercayaan diri pada penderita skoliosis di Masyarakat Skoliosis Indonesia dengan arah positif. Hal ini berarti jika religiusitas tinggi maka kepercayaan diri pada penderita skoliosis di Masyarakat Skoliosis Indonesia juga tinggi, demikian juga sebaliknya semakin rendah religiusitas maka kepercayaan diri pada penderita skoliosis di Masyarakat Skoliosis Indonesia juga rendah.

Berikut tabel deskriptif statistik dari variabel religiusitas dan kepercayaan diri berdasarkan mean empirik: 
Tabel 3. Descriptive Statistic Variabel Religiusitas Dengan Kepercayaan Diri

\begin{tabular}{cccccc}
\hline Variabel & N & Mean & $\begin{array}{c}\text { Std. } \\
\text { Deviation }\end{array}$ & Minimum & Maximum \\
\hline Religiusitas & 72 & 147,74 & 14,004 & 113 & 181 \\
Kepercayaan Diri & 72 & 118,92 & 14,736 & 87 & 154 \\
\hline
\end{tabular}

Berdasarkan nilai mean empirik, kelompok-kelompok yang terpisah secara maka dapat dilakukan pengelompokan berjenjang menurut suatu kontinum yang mengacu pada kriteria berdasarkan atribut yang diukur (Azwar, pengkategorisasian dengan tujuan 2014), dengan ketentuan pada tabel 4 menempatkan individu kedalam berikut :

Tabel 4. Norma Kategorisasi

\begin{tabular}{cc}
\hline Norma & Kategorisasi \\
\hline$X<(\mu-1,0 \sigma)$ & Rendah \\
$(\mu-1,0 \sigma) \leq X<(\mu+1,0 \sigma)$ & Sedang \\
$(\mu+1,0 \sigma) \leq X$ & Tinggi \\
\hline
\end{tabular}

Keterangan:

$\mu=$ mean atau rata-rata

$\sigma=$ standar deviasi

$\mathrm{X}=$ raw score

Berdasarkan norma di atas, diperoleh variabel Religiusitas dan kepercayaan diri kategorisasi subjek penelitian pada pada tabel 5 sebagai berikut:

Tabel 5. Kategorisasi Variabel Religiusitas dan Kepercayaan Diri

\begin{tabular}{lcccc}
\hline \multicolumn{1}{c}{ Variabel } & Skor & Jumlah & Persentase (\%) & Kategori \\
\hline Religiusitas & $\mathrm{X}<104$ & 11 & $15 \%$ & Rendah \\
& $104 \leq \mathrm{X}<134$ & 50 & $70 \%$ & Sedang \\
Kepercayaan Diri & $134 \leq \mathrm{X}<104$ & 11 & $15 \%$ & Tinggi \\
Jurnal Fakultas Psikologi Universitas Wisnuwardhana Malang & 10 & $14 \%$ & Rendah \\
\hline & 101 & & P-ISSN: 0853-8050 \\
E-ISSN: 2502-6925
\end{tabular}




\begin{tabular}{cccc}
$104 \leq \mathrm{X}<134$ & 49 & $68 \%$ & Sedang \\
$134 \leq \mathrm{X}$ & 13 & $18 \%$ & Tinggi \\
\hline
\end{tabular}

Berdasarkan tabel 5 di atas, diperoleh gambaran bahwa 11 orang $(15 \%)$ penderita skoliosis di Masyarakat Skoliosis Indonesia memiliki religiusitas yang rendah, 50 orang $(70 \%)$ penderita skoliosis di Masyarakat Skoliosis Indonesia memiliki religiusitas yang sedang, dan 10 orang (14\%) penderita skoliosis di Masyarakat Skoliosis Indonesia memiliki religiusitas yang tinggi. Sementara itu terdapat 10 orang $(14 \%)$ penderita skoliosis di Masyarakat Skoliosis Indonesia yang memiliki kepercayaan diri yang rendah, 49 orang (68\%) penderita skoliosis di Masyarakat Skoliosis Indonesia yang memiliki kepercayaan diri yang sedang, dan 13 orang (18\%) penderita skoliosis di Masyarakat Skoliosis Indonesia yang memiliki kepercayaan diri yang tinggi. Adapun sumbangan efektif ( $R$ square) dari variabel religiusitas terhadap kepercayaan diri dapat ditentukan dengan menggunakan rumus koefisien determinan sebagai berikut:

$$
\begin{aligned}
\mathrm{KP} & =\mathrm{r}^{2} \times 100 \% \\
& =(0,681)^{2} \times 100 \% \\
& =46,37 \% \\
& =46 \%
\end{aligned}
$$

Keterangan:

$\mathrm{KP}=$ Nilai Koefisien Determinan

$\mathrm{r}=$ Nilai Koefisien Korelasi

\section{Pembahasan}

Berdasarkan hasil uji korelasi Product Moment (Pearson) di mana level of significant $(\alpha)$ 0,01 dan diperoleh nilai koefisien korelasi $\left(\mathrm{r}_{\mathrm{xy}}\right)=0.681$. Hasil penelitian tersebut sesuai dengan hipotesis yang diajukan yaitu terdapat hubungan yang signifikan antara religiusitas dengan kepercayaan diri pada penderita skoliosis di Masyarakat Skoliosis Indonesia. Semakin tinggi religiusitas semakin tinggi kepercayaan diri pada penderita skoliosis di Masyarakat Skoliosis Indonesia. Sebaliknya semakin rendah religiusitas, maka semakin rendah kepercayaan diri 
pada penderita skoliosis di Masyarakat

Skoliosis Indonesia. Hal ini sejalan dengan pendapat Mukti (2013) keyakinan akan membuahkan kepasrahan dan kepercayaan bahwa segala sesuatunya itu sudah ditentukan oleh yang di atas. Pada keyakinan ini agama memegang peranan penting sebagai pegangan hidup penderita. Agama akan membantu penderita dalam memaknai hidupnya dan akan terealisasikan dalam sistem hidup, sikap dan perilaku serta pikiran yang positif.

Daradjat (dalam Octarina, 2008) mengatakan bahwa agama mempunyai fungsi dalam kehidupan manusia, yaitu memberikan bimbingan dalam kehidupan manusia, yaitu memberikan bimbingan dalam hidup, penolong dalam kesukaran, penentram batin, sehingga ketika seseorang mengalami suatu hal yang tidak sesuai dengan apa yang diinginkannya dan timbul pikiran-pikiran negatif dalam diri seseorang, dan dia memiliki keyakinan beragama, maka religiusitasnya akan berfungsi. Dia akan membuang pikiranpikiran negatif tersebut dan mengubahnya menjadi pikiran-pikiran yang positif. Hal ini senada dengan hasil penelitian yang dilakukan Lindawati (dalam Khoesdianto, 2009) bahwa individu dengan tingkat religiusitas yang tinggi akan mengarahkan diri pada hal-hal yang positif sehingga individu tersebut tidak memandang setiap kesukaran atau ancaman terhadap dirinya dengan cara negatif, melainkan melihat bahwa di celah kesukaran-kesukaran tersebut terdapat harapan-harapan. Hal ini sesuai dengan salah satu aspek yang terkandung dalam kepercayaan diri, yaitu individu memiliki harapan positif dalam memandang sesuatu. Adapun besar sumbangan efektif ( $R$ square) dari variabel kepercayaan diri terhadap religiusitas adalah sebesar $46 \%$ dan sisanya sebesar $54 \%$ dipengaruhi oleh faktor lain seperti konsep diri, harga diri, pengalaman dan pendidikan. 


\section{KESIMPULAN DAN SARAN}

\section{Kesimpulan}

Berdasarkan hasil penelitian dapat

ditarik kesimpulan bahwa terdapat hubungan antara religiusitas dengan kepercayaan diri dengan arah positif dan signifikan pada anggota Masyarakat Skoliosis Indonesia, semakin tinggi religiusitas maka semakin tinggi kepercayaan diri pada penderita skoliosis di Masyarakat Skoliosis Indonesia, demikian juga sebaliknya semakin rendah religiusitas maka semakin rendah kepercayaan diri pada penderita skoliosis di Masyarakat Skoliosis Indonesia

\section{Saran}

Ada beberapa saran yang dapat dikemukakan terkait dengan hasil penelitian, aitu:

1) Bagi Subjek Penelitian disarankan agar dapat menghayati dan menginternalisasikan ajaran agama sehingga berpengaruh dalam segala tindakan dan pandangan hidup serta mengembangkan penilaian positif terhadap kelemahan-kelemahan yang dimiliki.

2) Bagi peneliti selanjutnya yang ingin meneliti tentang tema yang sama disarankan untuk melihat variabel lain seperti konsep diri, harga diri, pengalaman dan pendidikan.

\section{DAFTAR RUJUKAN}

Adillani, Muharromah. 2015. Pengaruh Pemberian Terapi Latihan Metode Schrothterhadap Skoliosis pada Usia 10-12 Tahun Di Sekolah Dasar Negeri 1 Blulukan. Skripsi (tidak diterbitkan). Surakarta: Fakultas Ilmu Kesehatan.

Alfiana, Eva Novi. Wulan, Roro Retno, Malau, Ruth Mei Ulina. 2016. Konsep Diri Remaja Penderita Skoliosis (Studi Fenomenologi Masyarakat Skoliosiss Indonesia di Kota Bandung. E-proceeding Of Management: Vol 3 No 2 Agustus

Astuti, Sari. 2008. Hubungan Antara Religiusitas Dan Perilaku Seksual Pranikah Pada Remaja Yang Beragama Islam. Skripsi (Tidak 
diterbitkan). Medan: Fakultas Psikologi.

Azwar, Saifuddin. 2014. Metode Penelitian. Yogyakarta: Pustaka Pelajar.

— , Saifuddin. 2014. Penyusunan Skala Psikologi. Yogyakarta: Pustaka Pelajar

Fatimah, Enung. 2010. Psikologi Perkembangan (Perkembangan Peserta Didik). Bandung: Pustaka Setia

Faturrahman

Afrian.

2013.

Penatalaksanaan Fisioterapi Pada

Scoliosis Vetebra Thoracal 7 -

Lumbal 1 Di Rsal Dr.Ramelan.

Skripsi (tidak diterbitkan). Surakarta:

Fakultas Ilmu Kesehatan.

Fera. 2015. Pengaruh Body Image Terhadap Self-Esteem Pada Remaja Penderita Skoliosis. Skripsi (tidak diterbitkan). Medan: Fakultas Psikologi.

Ghufron M. Nur, Rini Risnawita S. 2010. Teori-teori Psikologi. Yogyakarta: Ar ruz Media.

Hanum, Septi, dan Nilamsari, Paramita. 2009. Berdamai dengan Skoliosis. Surabaya: CV Terang Terus.
Khoesdianto, Denny. 2009. Hubungan antara Religiusitas dan Kepercayaan Diri pada Muda-Mudi Komunitas Tritunggal Mahakudus di Surabaya. Tesis (tidak diterbitkan). Surabaya: Fakultas Psikologi.

Mukaromah, Siti. 2011. Pengalaman Psikososial Remaja Penyandang Skoliosis Di Wilayah Karesidenan Surakarta, Jawa Tengah. Tesis (tidak diterbitkan). Depok: Fakultas Ilmu Keperawatan.

Mukti, Dwi Invesningtyas dan Dinar Sari Eka Dewi. 2013. Hubungan Antara Religiusitas Dengan Penerimaan Diri Pada Pasien Stroke Iskemik Di Rsud Banjarnegara. Jurnal Universitas Muhammadiyah Purwokerto Tahun 11 No.2. Juli 2013.

Octarina, Frida Corry dan H Fuad Nashori. 2008. Hubungan Religiusitas Dengan Berpikir Positif Pada Remaja Putri. Skripsi (Tidak diterbitkan). Yogyakarta: Fakultas Psikologi dan Ilmu Sosial Budaya.

Papalia, D.E., Olds, S.W., \& Feldman, R.D. 2009. Human Developmen (penterjemah Brian Marwensdy). Jakarta: Salemba Humanika. 
Pratama, Hendriko. 2015. Hubungan Religiusitas Dengan Perilaku Konsumtif Pada Mahasiswi Tingkat Awal Di Universitas Pendidikan Indonesia (Upi) Bandung. Skripsi (Tidak diterbitkan. Bandung: Fakultas Psikologi.

Putri, Tria Anggarini. 2015. Hubungan Antara Body Image Dengan Kepercayaan Diri Mahasiswi Yang Mengalami Obesitas. Skripsi (Tidak diterbitkan). Surakarta: Fakultas Psikologi.

Rombe, Sufrihana. 2014. Hubungan Body Image dan Kepercayaan Diri dengan Perilaku Konsumtif Pada Remaja Putri di SMA Negeri 5 Samarinda. Jurnal Universitas Mulawarman Vol 2 No 1, 2014.

Reza, Iredho Fani. 2013. Hubungan Antara Religiusitas Dengan Moralitas Pada Remaja Di Madrasah Aliyah (MA). Jurnal UIN Syarif Hidayatullah Vol. 10 No. 2. Agustus 2013.

Rosadi, Rakhmad. 2009. Hubungan Kebiasaan Duduk Terhadap Terjadinya Skoliosis Pada Anak Usia 11-13 Tahun Di SD Pabelan Kartasura. Skripsi (Tidak diterbitkan). Surakarta: Fakultas Ilmu Kesehatan.

Sugiyono. 2013. Metode Penelitian Kuantitatif Kualitatif dan $R \& D$. Bandung: Alfabeta.

Undang-Undang Republik Indonesia Nomor 36 Tahun 2009 Tentang Kesehatan.

Utami. 2009. Hubungan Antara Dukungan Orang Tua Dengan Kepercayaan Diri Pada Remaja Tuna Rungu. Skripsi. (Tidak Diterbitkan) Jurusan Psikologi Fakultas Ilmu Pendidikan Universitas Negeri Semarang

Wahaningsih, Musiatun. 2012. Hubungan Antara Religiusitas, Konsep Diri, Dan Dukungan Sosial Keluarga Dengan Prestasi Belajar Pada Siswa Smp Muhammadiyah 3 Depok Yogyakarta. Jurnal Psikologi.

Wahyuni, Sri. 2014. Hubungan antara kepercayaan diri dengan Kecemasan berbicara di depan umum Pada mahasiswa psikologi. Jurnal Psikologi Vol. 2 No.1. 
Weiss, Hans Rudolf. 2013. Saya Menderita

Skoliosis (penerjemah Michael

Wong). Jerman: LAP

LAMBERTAcademic Publishing. 